\title{
MULTIPURPOSE ELECTRON BEAM WELDING MACHINE
}

\author{
V. Nesterenkov, K. Khrypko, V. Lukyanov \\ E.O. Paton Electric Welding Institute of the NAS of Ukraine. 11 Kazimir Malevich Str., 03150, Kyiv. \\ E-mail: office@paton.kiev.ua
}

\begin{abstract}
The Electric Welding Institute named after E. O. Paton has been specializing for many decades in electron-beam welding (EBW) techniques for many modern structural alloys, including the development of EBW equipment and related production methods. The past two decades, the Electric Welding Institute designed and manufactured a lot of units, used for EBW of various products. All these units can be roughly divided into several types according to the welding chamber volume : «small», «medium», «large» and «extra large». 6 Ref., 3 Fig.
\end{abstract}

\section{Keywords: electron beam welding machine, control system, graphical user interface}

The Electric Welding Institute designed and manufactured the KL-115 (Fig. 1) multipurpose electron beam welding machine. The machine has an internal welding electron beam gun located on the cantilever mechanism with 5 degrees of freedom, namely gun motion along the three Cartesian coordinate axes $X, Y, Z$ and its tilting in two cross planes [1]. To rotate all kinds of welded rotation figures, the machine is equipped with 3 different welding positioners: with a horizontal axis of workpiece rotation (equipped with a corresponding tailstock to support long parts), with a vertical axis of rotation and with an inclinable $\left(0 \ldots 90^{\circ}\right)$ axis of rotation. Thus, the machine has 7 movable mechanical axes controlled by the CNC (with the ability to control up to 4 axes at the same time), which, together with a sufficiently large volume of the welding chamber, provides very wide technological capabilities of the welding machine $[2,3]$. At the same time, although it can be used for welding both linear and curved seams of workpieces of any suitable shape and size for many industries, but, given the configuration, the emphasis here is primarily on the possibility of welding rotation figures, namely various rather big elements of aircraft engines and similar products.

The machine has an up-to-date control system (Fig. 2) on the base of a complete industrial system Sinumerik 840Dsl of the company Siemens [4]. Part of equipment, which is exerting influence on the welding process, is under continual program control.

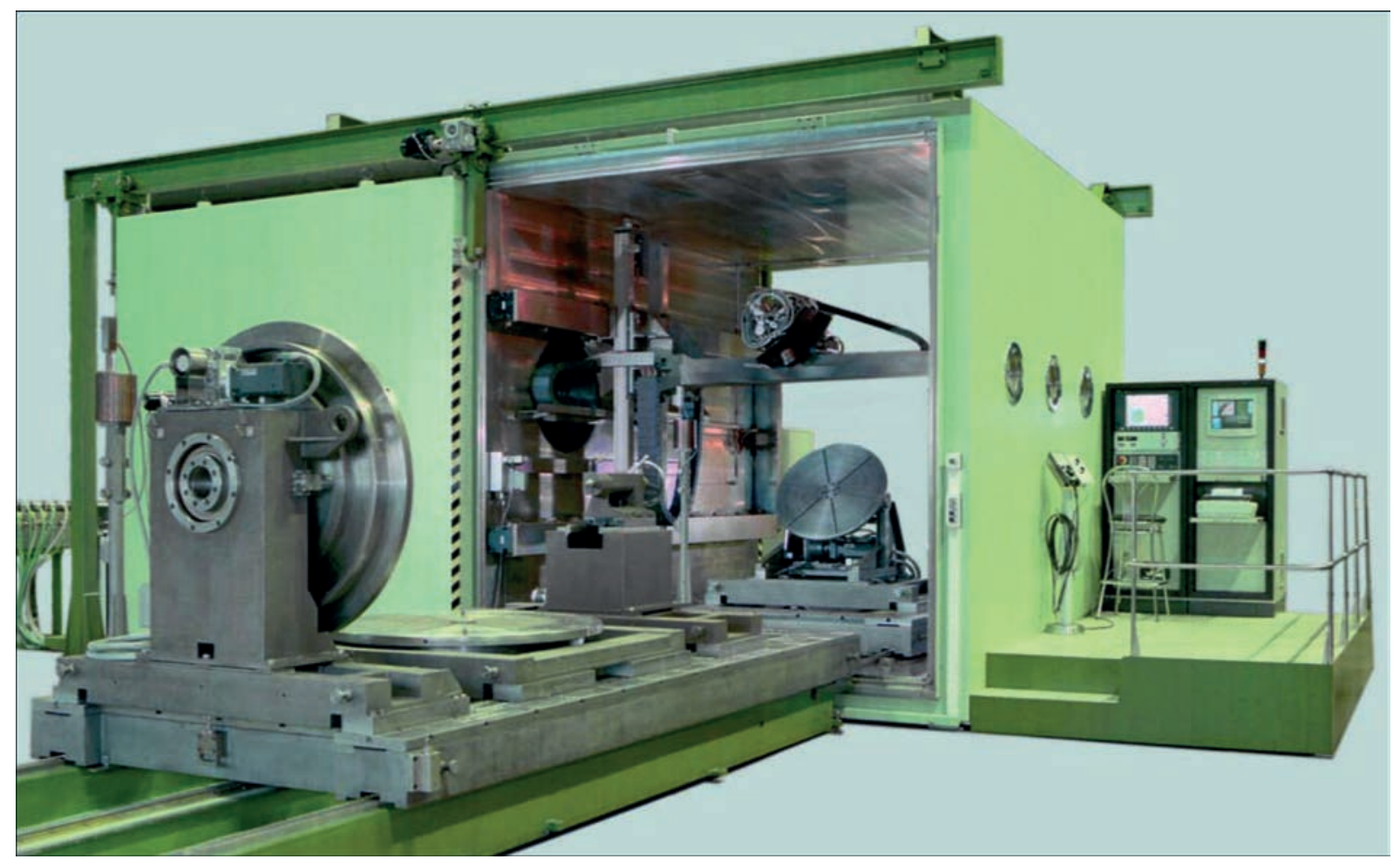

Fig. 1. KL-115 electron beam welding machine

(C) V. Nesterenkov, K. Khrypko, V. Lukyanov, 2019 


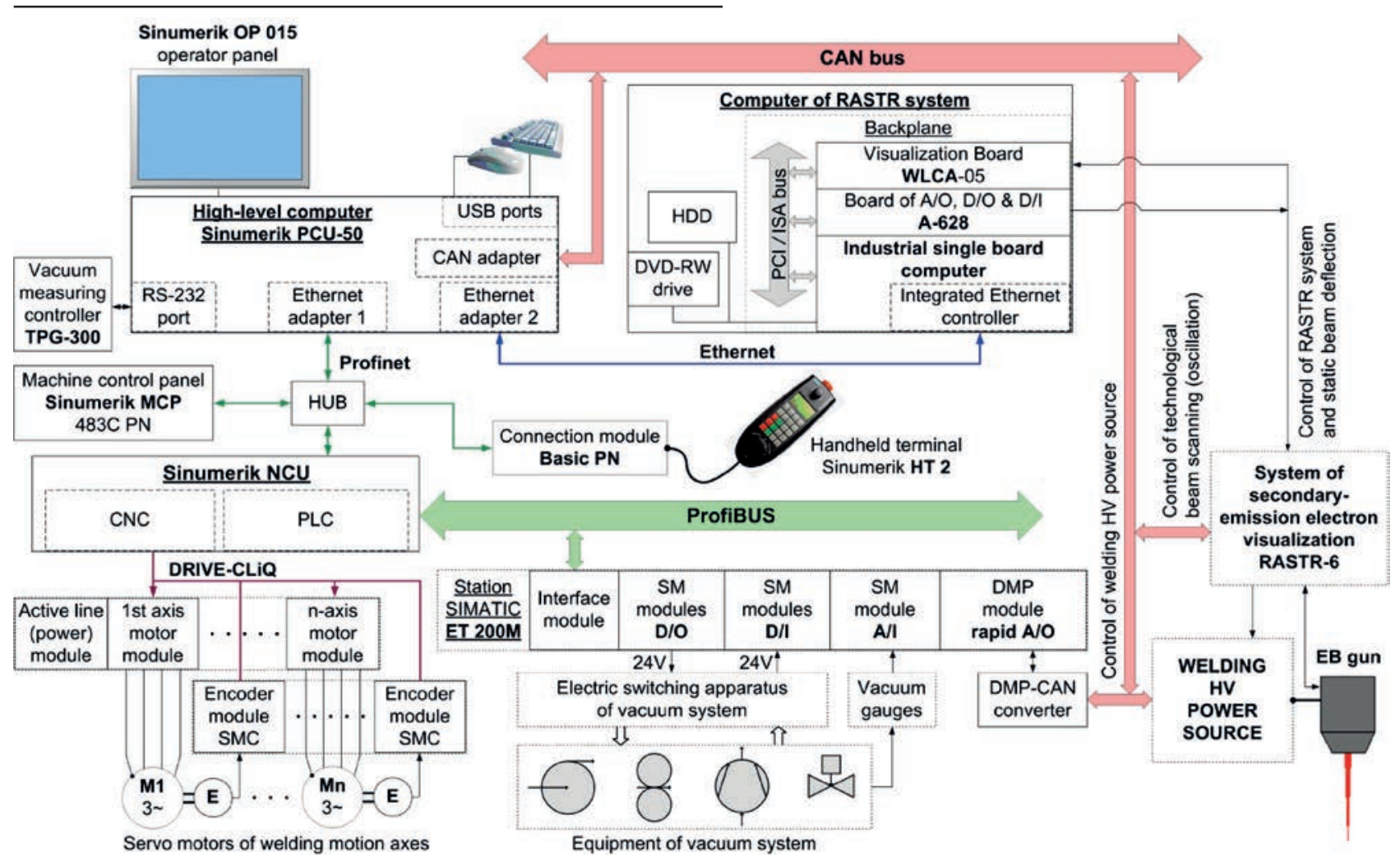

Fig. 2. KL-115 machine control system diagram

The concept of high-level software control, in which the user interacts with the equipment exclusively via the Windows-oriented graphical user interface (GUI), is used. The operation with GUI is made by using conventional standard tools: a keyboard and a mouse. The interface is intuitively conceivable (easy-to-understand) and doesn't require any specific skill. Each of the machine's subsystems is served by the appropriate window-based graphic tools with input data validation and safety locks to ensure the user and equipment protection.

Hierarchically, the control system is divided into two hardware and software levels, namely upper and lower. The upper level includes all means of communication with the user, including the GUI [5], means of creation and storage of specific welding programs (including collection of several welding subprograms with shared trajectory into one user program, for instance, tack run, welding run and cosmetic run), collection and storage of diagnostic data (including welding parameters), administration, etc. The lower level is engaged in the direct execution of all procedures under the instruction from the upper level.

At that the upper-level control program operates on the industrial computer Sinumerik PCU 50. The upper level interacts directly with the lower level elements, namely: the machine control panel (MCP), the main module NCU and connection module Basic $\mathrm{PN}$, to which the mobile handheld terminal HT 2, used for the gun or weldment manual motion, is connected

Welding motion is under the CNC complete control both in the manual movement mode and at automatic welding mode. In the latter case, the text script of the prepared welding program is transmitted from the upper level to the NCU, where CNC makes a full calculation of the trajectory, proper interpolations, speeds and accelerations for each of the axes involved. CNC provides complete synchronization of all axes, both mechanical and virtual. As virtual axes, the channels of welding and focusing currents, as well as the channel of electron beam technological oscillation, are used [6]. At that the control assignments of these axes are

taken from the DMP module of rapid analog outputs of the station ET $200 \mathrm{M}$ and converted into the CAN bus protocol (from which the high-voltage welding power supply is controlled).

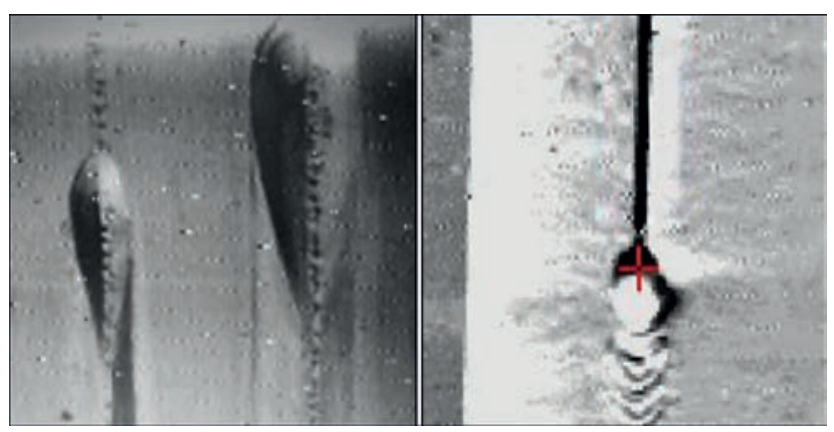

Fig.3. The secondary-emission image of welded surface 
Also the upper level interacts with the additional lower level element - the computer of the «RASTR-6» subsystem, which operates on the principles of a scanning electron microscope and makes it possible in real time to observe on upperlevel program GUI the secondary-emission image of welded surface (Fig. 3) before/after and during the welding process, precisely manually to aim the electron beam on any butt to be welded, as well as gives the data for operation of special automated algorithms of the weld butt "search» at both automatic teach-in (creation) of a new complicated curvilinear trajectory and correction of an existing trajectory immediately before welding of any serial product.

The PLC (Programmable Logic Controller) of NCU fulfills safe automatic control of vacuum system using digital and analog inputs/outputs of the station ET 200M.

\section{Main technical parameters of KL-115 machine}

Overall machine dimensions

(length $\times$ width $\times$ height), $\mathrm{mm}$. $15960 \cdot 10300 \cdot 3740$

Weight, tons 48

Vacuum chamber internal size

(length $\times$ width $\times$ height), $\mathrm{mm}$

$4040 \cdot 2950 \cdot 2950$

Working pressure in vacuum chamber, torr,

not worse than $2.5 \cdot 10^{-4}$

Working pressure in EB gun, torr, not worse

than $5 \cdot 10^{-5}$

Pump-down time before working pressure in chamber and $\mathrm{EB}$ gun is obtained, minutes, max
EB gun movement (with positioning accuracy $\pm 0.1 \mathrm{~mm}$ ) stroke along coordinates $X, Y$

and $Z, \mathrm{~mm}$ 3000,1800 and 2000

EB gun linear movement speed, $\mathrm{mm} / \mathrm{s}$ $1.66 \ldots 33.3$

EB gun rotation angle (with accuracy $0,1^{\circ}$ ) in $X$ - $Y$ plane,

degrees..... 90

EB gun rotation angle (with accuracy $0,1^{\circ}$ ) in $X$ - $Y$ plane,

degrees ........................................................................ \pm 90

Electron beam gun and power supply: ... $60 \mathrm{~kW} / 60( \pm 0.06 \mathrm{kV})$

- Metal cathode life-time, hours ............................................ 40

- Beam deflection angle, degree ...................................... $\pm 3,5$

«RASTR-6» resolution upon observation, $\mathrm{mm}$..................... 0.1

Equipped water chiller ......................................................... Yes

Mains supply (according to German Standards

DIN EN 60 204-4.3)

$380,50 / 60 \mathrm{~Hz}, 250 \mathrm{kVA}$

\section{References}

1. Nazarenko O.K., Nesterenkov V.M., Neporozhny Yu.V. (2001) Design and electron beam welding of vacuum chambers. The Paton Welding J., 6, 40-42.

2. LaFlamme G., Mac Williams S., Rugh J., Hendryx R.. (2006) Hybrid EBW Process Joining Heavy-Duty Impellers. Welding Journal, 1, p.44-47.

3. Myers L., LaFlamme G. (2000) Electron beam braze welding of compressor impellers. The Paton Welding J., 8, 53-57.

4. Paton B.E., Nazarenko O.K., Nesterenkov V.M. et al. (2004) Computer control of electron beam welding with multicoordinate displacements of the gun and workpiece. The Paton Welding J., 5, 2-5.

5. Nesterenkov V.M., Khripko K.S. (2017) Recent achievements of E.O. Paton Electric Welding Institute in development of equipment for electron beam welding. Zvaroc professional. 2, 9-13.

6. Nazarenko O.K., Nesterenkov V.M., llyushenko R.V. (2005) Weldability of aircraft aluminium alloys of great thickness in EBW. The Paton Welding Journal, 8, 25-31.

\section{УНІВЕРСАЛЬНА ЕЛЕКТРОННО-ПРОМЕНЕВА ЗВАРЮВАЛЬНА УСТАНОВКА}

В. Нестеренков, К. Хрипко, В. Лук’янов

IE3 ім. Є.О. Патона НАН України. 03150, м. Київ, вул. Казимира Малевича, 11. E-mail: office@paton.kiev.ua

Інститут електрозварювання ім. Є.О. Патона протягом багатьох десятиліть спеціалізується на розробці технології електронно-променевого зварювання (ЕПЗ) сучасних конструкційних сплавів, включаючи розробку обладнання ЕПЗ і пов'язаних з ним методів виробництва. За останні два десятиліття IE3 розробив і виготовив безліч установок, використовуваних для ЕПЗ різних виробів. Всі ці установки можна умовно розділити на кілька типів залежно від обсягу зварювальної камери: «малі», «середні», «великі» і «дуже великі». Бібліогр. 6, рис. 3.

Ключові слова: електронно-променева зварювальна машина, система управління, графічний інтерфейс користувача

\section{YOUNG PROFESSIONALS INTERNATIONAL CONFERENCE ON WELDING AND RELATED TECHNOLOGIES}

19-22 May, 2020, Kyiv, Ukraine

https://ypic2020.com

Щорічна конференція-виставка

«НЕРУЙНІВНИЙ КОНТРОЛЬ-2020»

Травень 2020 р., Київ, «Асоціація «ОКО»

http://www.ndt.com.ua

Міжнародна конференція

«ТИТАН 2020: ВИРОБНИЦТВО ТА ЗАСТОСУВАННЯ»

1-3 червня 2020 р., Київ, IEЗ ім. Є.О. Патона НАН України

тел.: 38044 200-82-77, journal@paton.kiev.ua, http://pwi-scientists.com/rus/titan2020 